\title{
Magdalena Toboła-Feliks
}

Polskie Towarzystwo Ludoznawcze Oddział Cieszyn

(D) https://orcid.org/0000-0002-5421-9484

\section{Profanacja czy innowacja? Dekonstrukcja stroju ludowego w konwencji folk fashion*}

\begin{abstract}
An Instance of Profanation or Innovation? Deconstructing Folk Costumes according to Folk Fashion Convention
\end{abstract}

\begin{abstract}
In the fashion world of today there appears an increasing number of projects whose overall theme are traditional folk costumes. On the one hand, designers embark upon representing folk costumes faithfully, yet on the other, only some reverberations are present in the "folk fashion" current, whose framework encompasses aleatoric associations of native patterns that compose a peculiar type of axiological mosaic. The foregoing constitutes a stimulus for cultural-imbued creativity, while concurrently being an alternative for mass production. In many cases, attempts to resuscitate tradition translate into space for re-interpreting it, the ramification of which is, in turn, a challenging research area for contemporary ethnology and cultural anthropology.
\end{abstract}

Keywords: folk costumes, deconstructing tradition, folk fashion, cultural and religions studies

Słowa kluczowe: strój ludowy, dekonstrukcja tradycji, folk fashion, nauki o kulturze i religii

Tematyka strojów ludowych jest rozpatrywana $\mathrm{z}$ wielu perspektyw. Zagadnienie to wpisuje się bowiem w obszar badawczy wielu dyscyplin naukowych w Polsce i innych krajach europejskich ${ }^{1}$. Mimo że stroje ludowe konotują przekaz nie

" Informacje o źródłach finansowania badań przedstawionych w artykule: tekst powstał na podstawie badań własnych.

${ }^{1}$ Przykładem są chociażby wydawnictwa czeskie i słowackie, w których strój ludowy jest prezentowany jako jeden $\mathrm{z}$ wątków tematycznych rozpatrywanych na tle całokształtu kultury ludowej 
mieszczący się $\mathrm{w}$ ich wizualności, $\mathrm{w}$ badaniach etnograficzno-antropologicznych opisywane są zazwyczaj z perspektywy regionalnej². W analizach uwzględnia się użyteczność oraz znaczenie społeczne stroju ludowego, a także jego aspekt estetyczno-artystyczny. W licznych muzeach, nie tylko stricte etnograficznych, odnajdziemy kolekcję regionalnych strojów ludowych ukazującą obowiązujące w kulturze tradycyjnej zasady „mowy stroju”. Ten, poprzez wielorakość pełnionych funkcji, był zawsze artefaktem istotnym w życiu mieszkańców wsi.

Należy jednak zaznaczyć, że w niniejszych rozważaniach strój ludowy nie jest ujmowany $\mathrm{w}$ sensie somatycznym ${ }^{3}$. Są one skoncentrowane raczej na semiotycznych kontekstach działań $\mathrm{w}$ sferze mody inspirowanych tradycyjnymi elementami stroju ludowego, stąd też celowo w tekście jest stosowane sformułowanie „strój ludowy” w szerszym niż w tzw. etnografii tradycyjnej znaczeniu4. Ze względu na wielowątkowość omawianego tematu artykuł stanowi jedynie początek dalszych poszukiwań badawczych mających na celu zgłębienie problematyki wykorzystania w modzie elementów nawiązujących do stroju ludowego,

(np. J. Langhammerová: České tradice v proměnách času. Kroje - zvyky - umění. Praha 2017), publikacje traktujące wyłącznie o strojach ludowych, gdzie osobno omawiany jest strój charakterystyczny dla danego regionu bądź grupy (np. B. ŠotкovÁ: Naše lidové kroje, jejich vzory, střihy a zpracování. T. 1-8. Praha 1951-1952), opracowania odnoszące się do konkretnego elementu stroju, jego zdobnictwa (np. Z. VANíčKová: Čepec - součást horáckého lidového oděvu ženy na Telčsku na počátku 19. Století. W: Jubilejní pátá zpráva Muzejního spolku v Telči za r. 1992-1996. Praha 1997, s. 70-82; O. DAglová: Dekor symbol. Dekoratívna tradícia na Slovensku a európsky kontext. Bratislava 2001, s. 240-254) czy wreszcie te, w których strój ludowy postrzega się jako źródło różnorakiej inspiracji (np. M. PACHTová: Depozitár muzea - zdroj inspirace a poučení o lidovém kroji na Vyškovsku. W: Lidový oděv a tanec na Hané. Vyškovsko 1998, s. 38-41; H. FišErová-KvĚchová: Lidové umění jako inspirační zdroj v díle Marie Fischerové-Kvěchové. „Studia Ethnologica Pragensia" 2016, číslo 1, s. 41-50).

${ }^{2}$ Wiodącym przykładem takiego ujęcia tematu jest seria wydawnicza Polskiego Towarzystwa Ludowego Atlas Polskich Strojów Ludowych, w ramach której publikowane są zeszyty ukierunkowane tematycznie na określony region - obszar występowania danego stroju; np.: B. BAzIELICH: Strój opolski. W: Śląsk. Z. 7. Wrocław 2008 (Atlas Polskich Strojów Ludowych. Red. J. KaмоскI. T. 38. Cz. 3); J. Minksztym: Strój Bambrów Poznańskich. W: Wielkopolska. Z. 6. Wrocław 2015 (Atlas Polskich Strojów Ludowych. Red. A.W. Brzezińska. T. 47. Cz. 2); A. WoźNiak: Strój łęczycki. W: Mazowsze i Sieradzkie. Z. 10. Wrocław 2014 (Atlas Polskich Strojów Ludowych. Red. J. SŁOMsкA-Nowak. T. 43, cz. 4). Innym przykładem są publikacje obejmujące grupy strojów ludowych wyróżnione z perspektywy położenia geograficzno-historycznego, a tym samym również przynależności administracyjnej. Wówczas teren badawczy zostaje poszerzony, mimo że sama analiza nadal opiera się głównie na zróżnicowaniu terytorialnym; np. B. BAzIELICH: $Z$ bliska i $z$ oddali. Stroje ludowe na Ślasku. Katowice 2017. W literaturze przedmiotu odnajdziemy również swoiste kompendia dotyczące strojów ludowych, opracowane w odniesieniu do terytorium danego kraju czy grupy krajów; np.: E. Piskorz-Branekova: Polskie stroje ludowe. Warszawa 2008; B. BAZIELICH: Kolory Europy. Odzież i stroje ludowe. Katowice 2008.

${ }^{3}$ B. BAzIelich: $Z$ bliska $i z$ oddali..., s. 10.

${ }^{4}$ A. W. Brzezińska, J. SŁomska-Nowak: Czy i jak badać strój ludowy? W: Etnologiczne $i$ antropologiczne obrazy świata - konteksty i interpretacje. Red. H. Rusek, A. Pieńczak. Cieszyn 2011, s. 62-74. 
ich selekcjonowania, wprowadzania, a także późniejszej adaptacji do aktualnie obowiązujących trendów modowych ${ }^{5}$.

\section{Folk fashion niejedno ma imię}

Na przestrzeni ostatnich kilku dekad folk fashion przyczynił się do zasadniczej zmiany polegającej na reinterpretacji znaczenia stroju chłopskiego. Rodzime stroje ludowe, wcześniej niemal bezrefleksyjnie kojarzone z występami zespołów folklorystycznych lub z zaściankowością Cepelii pachnącej starością, obecnie coraz częściej przybierają nowoczesne formy, stanowiące reminiscencje przeszłości. Ludowość została odkryta ponownie, jako unikalne źródło twórczej inspiracji określającej estetykę nowych trendów. Młode pokolenie polskich designerów, poszukując właściwej jedynie sobie formy wyrazu artystycznego, oparło się na tradycji traktowanej w kategorii szansy, nie zaś zagrożenia dla twórczych działań. Tym samym w wielu przypadkach umiejętne połączenie tradycyjnych elementów stroju ludowego ze świeżym, innowacyjnym spojrzeniem przyniosło unikatowe wytwory o zaskakującej wartości. Stają się one obecnie wizytówką promującą Polskę na świecie. Na ludowość niewątpliwie panuje moda, musimy jednak mieć świadomość, że moda inspirowana ludowymi wzorami nie jest niczym nowym ${ }^{6}$. Motywy ludowe od dawna powracają, z różnym natężeniem, stanowiąc punkt wyjścia wielu projektów; jest to jednak ludowość specyficzna, ulokowana nieco poza głównym nurtem zainteresowań etnograficznych. Na potrzeby niniejszego artykułu nazwijmy ją zatem, za Piotrem Kordubą, ludowością na sprzedaż ${ }^{7}$ oznaczającą swoistą komercjalizację, specyficzne przewartościowanie kultury ludowej w obrębie określonych jej elementów, co z kolei staje się główną determinantą różnych działań.

${ }^{5}$ Por. K. Czerwińska: Strój jako wyzwanie artystyczne. W: Eadem: Przepakować dziedzictwo. Przeszłość jako projekcja rzeczywistości - przypadki ślaskie. Katowice 2018, s. 126-132; A.W. Brzezińska: Strój ludowy - od biografii przedmiotu do tożsamości podmiotu. W: Stroje ludowe jako fenomen kultury. Red. A.W. Brzezińska, M. Tyмосноwicz. Wrocław 2013 (Atlas Polskich Strojów Ludowych. Zeszyt specjalny), s. 15-24; S. Trebunia-Staszel: Podhalańskie elegantki i miejscowi kreatorzy mody. W: Stroje ludowe jako fenomen kultury..., s. 119-130.

${ }^{6}$ Inspiracje strojem ludowym znajdujemy już u Stanisława Witkiewicza; kreowany przez niego styl zakopiański sprawił, że autentyczna sztuka ludowa Podhala została poddana artystycznej modyfikacji aspirującej do miana stylu narodowego. Z kolei chociażby w twórczości Stanisława Wyspiańskiego obserwujemy wyraźne analogie do huculszczyzny. Swoiście pojmowana stylistyka nawiązująca do ludowej pojawia się także w twórczości Zofii Stryjeńskiej (oraz wielu innych twórców awangardy międzywojnia).

7 Zob. P. Korduba: Ludowość na sprzedaż. Warszawa 2013. 


\section{Moda spod strzechy - eksplozja mempleksu folk fashion}

Codzienne potrzeby oraz styl życia ulegają niezwykle intensywnym transformacjom, mimo to cel projektantów pozostaje w zasadzie niezmienny. Jest nim subtelne łączenie kultury ludowej z tym, co reprezentują aktualnie obowiązujące trendy. Wobec tego intencją $\mathrm{w}$ folk fashion jest zespalanie użyteczności danego wytworu z tym, co kolektywnie przyjmujemy za estetycznie pożądane, a co w sposób pośredni nawiązuje swą stylistyką do strojów ludowych. Odchodząc od techniczno-konstrukcyjnej wizji i sięgając poza kwestie merkantylne, współczesna moda $\mathrm{w}$ stylistyce folk zyskuje niezwykle wyrazisty charakter, w czego konsekwencji współczesną odzież nawiązującą do omawianego nurtu postrzegać możemy jako punkt, w którym zespalają się różnorodne przejawy tradycji. Kształtowanie formy artefaktów użytkowanych podczas prozaicznych czynności dnia codziennego (w tym przede wszystkim odzieży) to nie tylko dbałość o estetykę, ale również konstrukcja tożsamości ściśle związanej z określonym regionem ${ }^{8}$. Zakładając zatem, że twórczość tę należy rozpatrywać całościowo, a równocześnie zwracać uwagę na to, co jest jej inwariantem, za źródło postawy twórczej można uznać interioryzację.

Nie koncentrując się na stopniu trudności, jaki napotykamy przy próbach stworzenia jednoznacznej definicji, roboczo przyjmijmy, że folk fashion w swym najbardziej elementarnym znaczeniu to polimorficzny kompleks symboliczno-artystycznych działań odwołujących się między innymi do tradycji stroju ludowego. Jest nurtem wzornictwa propagującym zespolenie nowoczesnych trendów z elementami nawiązującymi stylistyką do dawnej odzieży paradnej. Odnosi się to zarówno do wplatania akcentów ludowych we współczesne projekty, jak i do odtwarzania archaicznych zasad i technik produkcji. W zależności od intencji twórcy wyartykułowanie paradygmatu omawianej dziedziny działalności może objawić się pod postacią cytatu zapożyczonego z obrębu kultury ludowej, mającego na celu przełamanie pewnych konwencji stylistycznych lub wzbogacenie ogólnego wyrazu projektu. Projektant może też pokusić się o umieszczenie tradycyjnych elementów w nowym kontekście, czyniąc z nich dominantę konceptu projektowego. Może wreszcie jedynie zainspirować się określonym ludowym motywem, nie przenosząc go wprost na tworzony projekt, w myśl założenia, że kwestia mody nie mieści się w sferze zagadnień dotyczących wierności jej wzorca. Może ponadto zastosować tradycyjne techniki wytwarzania stroju lub zespolić

${ }^{8}$ Możliwe jest tu także kreowanie tożsamości hybrydowej (w rozumieniu mieszania się oraz przenikania dopuszczalnych wariantów kultury rodzimej, otwartej jednakże na zapożyczenia kultur obcych). Niekiedy prowadzi to wręcz do kreacji tradycji wymyślonej czy też zjawiska cultural appropriation. Zob. Tradycja wynaleziona. Red. E. Hobsbawn, T. Ranger. Przeł. M. Godyń, F. GodyŃ. Kraków 2008. 
wybrane warianty. W wyniku tego rodzaju działań to, co znamy ze świata wiejskich chat, w zderzeniu z kreatywnością młodych projektantów nabiera zupełnie nowego wyrazu, fascynującego swą innowacyjnością, skorelowaną z obrazami mocno ugruntowanymi $\mathrm{w}$ świadomości.

Spoglądając nieco z boku na współczesne wzornictwo, zauważamy gorączkowe poszukiwania $\mathrm{w}$ miarę autentycznych ludowych odniesień. Trudno to deprecjonować, choć niewątpliwie w niektórych przypadkach nie możemy mówić o wysublimowanym podejściu do tradycji. Być może płaszczyzną kompromisu pomiędzy „czystym” a poniekąd komercyjnym traktowaniem tradycyjnych wzorów jest przyjęcie wysokich kryteriów merytorycznych zarówno przez projektantów oferujących dany produkt, jak i przez odbiorców towarów folk fashion. Zabawa formą powinna przewidywać uprzednie poddanie tematu dogłębnej analizie, ludowość sztucznie przekładana na przedmioty w ostatecznym rozrachunku kłóci się bowiem $\mathrm{z}$ ich wizerunkiem, nie będąc w stanie wygenerować szczerości przekazu. Ludowość powinna zespalać się z przedmiotem, który staje się materialnie ujmowanym nośnikiem wieloaspektowo nacechowanej wartości. Podobną ideę znajdujemy już w fenomenologicznych założeniach Romana Ingardena ${ }^{9}$, dla którego punktem wyjścia twórczości jest spotkanie odpowiednio przygotowanego człowieka (wyposażonego $\mathrm{w}$ niezbędną wiedzę) i artefaktu (w naszym przypadku: stroju ludowego). Fascynacja wyodrębnionymi aspektami stroju każe szukać ich dopełnień. Dobry projektant bez większych problemów powinien łączyć funkcję $\mathrm{z}$ formą, tak by te od razu wywołały w nas intuicyjne skojarzenia, stwarzające wrażenie czegoś znajomego. Tego typu działania opierają się na skłonności ludzkiego umysłu do wypełniania pustych miejsc poprzez systematyzowanie wiarygodnych odniesień. Możemy zatem powiedzieć, że projektowanie rozpoczyna się od taksonomizacji analogii odruchowo pojawiających się w naszych głowach.

\section{Wylęgarnia innowacji czy ludowy miszmasz?}

Strój ludowy, stając się inspiracją we współczesnym wzornictwie, przeszedł na zupełnie inny poziom asocjacyjny. To z kolei stało się przyczynkiem do postawienia pytania: czy jest to tylko bezrefleksyjne czerpanie $\mathrm{z}$ fałszywie pojmowanej tradycji nastawione na zysk czy raczej faktyczna fascynacja elementami tradycyjnymi i swoista chęć powrotu do korzeni? Odpowiadając, należy zwrócić uwagę na to, że współcześnie coraz wyraźniej zaznacza się trend, w którym etniczny wątek tożsamościowy zyskuje na znaczeniu, aczkolwiek nie zamyka się przy tym na inne nurty, wpływając na kształtowanie gustów w stylistyce etno czy

\footnotetext{
${ }^{9}$ Zob. R. Ingarden: Studia $z$ estetyki. T. 3. Warszawa 1975.
} 
folk $k^{10}$. Dostrzegalna tu prosta parafraza binarnych opozycji Claude’a Lévi-Straussa stała się zalążkiem nowej dziedziny aktywności twórczej, zachęcającej do zagłębienia się w świat zachwycający feerią barw. Istotne jest tu przede wszystkim to, że strój ludowy, oscylujący wokół niezwykłego bogactwa tradycyjnych odniesien, postrzegany często $\mathrm{w}$ charakterze eksponatu muzealnego bądź przedmiotu dociekań akademickich, poddany został redefinicji.

W wyniku różnorakich działań tradycyjne niegdyś wytwory stają się ogólnodostępnym towarem, eksponowanym na półkach „supermarketu kulturowego”. Ma to ważne implikacje, gdyż przeobrażenie tradycji w produkt funkcjonujący $\mathrm{w}$ warunkach współczesnego rynku może odzierać ową tradycję z pierwotnie dominujących wartości, nadając jednocześnie zupełnie nowe znaczenia jej poszczególnym składowym. Wspomniany „supermarket” to obszar kulturowy dzisiejszego świata dający nam nieskończoną możliwość wyboru składników

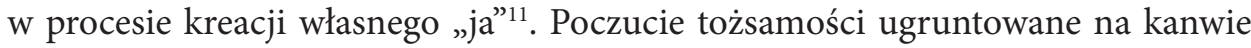
takich zabiegów może nawiązywać do określonych tradycji regionalnych, jednakże ocena jego zgodności z oryginałem niesie ze sobą spore kłopoty diagnostyczne. Należy zatem poddać metodologicznej analizie sytuacje, w których przejawy folk fashion zdają się cieszyć popularnością ze względu na te cechy kultury współczesnej, które skłaniają do utożsamiania jej z kulturą przedmiotów ${ }^{12}$. Założenie to wydaje się jasne, jednakże znaczenie niektórych dóbr jest częstokroć ujmowane poza ich aspektem materialnym, co komplikuje kwestię, prowadząc do jej transgranicznego podziału. Grant MacCraken jest zdania, że przedmioty są czymś zakorzeniającym nas w przeszłości. Poprzez materialno-tekstualne odniesienia unaoczniają nasze doświadczenia. Janusz Barański słusznie zauważa, że są związane $\mathrm{z}$ działaniami czasu przyszłego, stanowiąc swego rodzaju pomost między tym, co nadejdzie, a tym, co minione ${ }^{13}$. Wykorzystując zbędne przedmioty potrafimy stworzyć coś zupełnie nowego, czerpiącego, co prawda, z tej samej podstawy, ale wyraźnie innego, bo przystosowanego do odmiennych wymogów. Odnosimy się do ambicji nacechowanych pragnieniem manifestacji przynależności regionalnej, będących często iluzją rzeczywiście odczuwanych potrzeb tożsamościowych. Niemniej jednak kultura jest czymś, czym każda jednostka musi szczelnie obudować swoje życie, a wybór przynależności do określonej regionalnej tradycji kulturowej sprowadza się do „ometkowania” siebie jej wyznacznikami oraz ogólnego egzystencjalnego „ugadżetowienia”. W pewnym

${ }^{10}$ I. Kорутоғ: Kulturowa biografia rzeczy - utowarowienie, jako proces. W: Badanie kultury. Elementy teorii antropologicznej. Wybór i przedm. M. Kempny, M. Nowicka. Warszawa 2003, s. 249-251.

${ }^{11}$ Zob. G. Mathews: Supermarket kultury. Kultura globalna a tożsamość jednostki. Przeł. E. КLекот. Warszawa 2000; R. Sulima: Supermarket - przyczynek do retoryki konsumpcji. W: IDEM: Antropologia codzienności. Kraków 2002, s. 168-172.

${ }^{12}$ W.J. BurszTa: Świat jako więzienie kultury. Kraków 2008, s. 108.

${ }^{13}$ Por. J. Barański: Świat rzeczy. Zarys antropologiczny. Kraków 2007, s. 29. 
sensie zainteresowanie folk fashion wzrasta $\mathrm{z}$ kreowanego pragnienia powrotu do pierwotnych wartości i trwałości określonego systemu aksjologicznego ${ }^{14}$.

Oczywiście trzeba pamiętać, że $\mathrm{w}$ wielu przypadkach może to być zbyt kategoryczne stwierdzenie. Należy rozważać je jako jedną z możliwych dróg wnioskowania (zwłaszcza, że postrzeganie współczesnej mody funkcjonującej w obszarze tradycji jako depozytariusza minionego bogactwa przeobraża się niekiedy w brzemię). Kultura ludowa jest inspiracją interesującą, choć trudną w interpretacji. Ponadto miejmy na uwadze, że strój ludowy to swego rodzaju komunikat, niegdyś ściśle skodyfikowany i współtworzący przestrzeń życia społecznego. To wciąż manifestacja oraz estetyczna emanacja poczucia przynależności regionalnej ${ }^{15}$. Nie uwzględniając kontekstu, w jakim osadzone są poszczególne elementy stroju ludowego, łatwo możemy ulec złudzie etnograficznej rzeczywistości, którą sami kreujemy. Działania tego typu znajdują uzasadnienie, warto jednak zadać sobie pytanie, jaki jest ich rzeczywisty cel. Pogłębia się bowiem rozziew między tradycyjnie rozumianym etnograficznym obrazem polskiej wsi a jej rzeczywistością.

W wielu przypadkach futurystyczne próby wskrzeszenia tradycji mają na celu jedynie włączenie elementów stroju ludowego w obieg kultury popularnej. Rodzi to zatem pytania: Czy w dalszym ciągu każdy element stroju powinien być odczytany jako znaczący? Czy w dalszym ciągu element składający się na strój ludowy, przedstawiony w nowej odsłonie, będzie stanowił mariaż mody i znaczeniowości? Czy też, za sprawą zmiany kształtujących ten strój kryteriów formalnych oraz pod wpływem technologii wytwarzania, traci swój dotychczasowy status? $\mathrm{Na}$ te pytania odpowiemy, odwołując się do trzech przykładów. W odniesieniu do rodzimego rynku modowego wytypowane projekty, których adresatem jest młode pokolenie, są tu uznane za pionierskie, stanowiące inspirację dla późniejszych działań mieszczących się $\mathrm{w}$ ramach omawianego nurtu. Jako jedne $\mathrm{z}$ pierwszych odnosiły się one kompleksowo do założeń folk fashion, elementy stroju ludowego były wprowadzone konsekwentnie i świadomie. Modelowe realizacje cechuje znaczny dekonstruktywizm, choć nie brak w nich wyraźnych odniesień, sprawiających, że identyfikacja pierwowzoru następuje niemal natychmiastowo. Ponadto projektantki nawiązały do kultury ludowej rejonów im najbliższych (tych, z których pochodzą), możemy zatem pokusić się o wskazanie odwołań do poczucia lokalnego patriotyzmu i pewnego rodzaju sentymentu przejawianego względem określonej tradycji regionalnej, a w rezultacie - emocjonalne naznaczenie projektu, rozumiane jako wartość dodana ${ }^{16}$.

\footnotetext{
${ }^{14}$ J.L. Comarofff: Etniczność sp. z o.o. Przeł. W. Usakiewicz. Kraków 2001, s. 36-39.

15 A.W. Brzezińska: Strój ludowy - od biografii przedmiotu do tożsamości podmiotu. W: Stroje ludowe jako fenomen kultury..., s. 15-17.

${ }^{16}$ Podobne odniesienia znajdziemy także $\mathrm{w}$ innych dziedzinach twórczości, w tym szczególnie we współczesnym designie. Przykładem może być chociażby krzesło Zako, wykonane ze szkła organicznego, praktycznie niewidoczne, ale niepozostawiające wątpliwości interpretacyjnych (nawiązania do góralszczyzny regionu podhalańskiego), czy lampa She, inspirowana kieckami
} 


\section{Rodzime przykłady folk fashion}

Zacznijmy od kolekcji Agnieszki Wyrwał, reprezentującej markę własną AGA POU. To absolwentka Wydziału Tkaniny i Ubioru Akademii Sztuk Pięknych w Łodzi. Projektantka zauroczona prostotą stroju hrubieszowsko-tomaszowskiego ${ }^{17}$ stworzyła niezwykle spójną kolekcję „Zaplątani”" ${ }^{18}$, której efektowność zasadza się głównie na dość minimalistycznych, choć rzucających się w oczy detalach. W kolekcji odnajdziemy powracające motywy wiązań oraz elementy przywodzące na myśl zdobnictwo stroju wilanowskiego, z charakterystycznymi haftami sztachetowymi przedstawionymi tutaj $\mathrm{w}$ formie ręcznie przygotowanej wycinanki. Główną ozdobą tradycyjnego stroju hrubieszowskiego, do którego kolorystyką nawiązuje całość kolekcji, był haft krzyżykowy prezentujący wzory o motywach figuralnych, często przypominających zgeometryzowane rośliny. $\mathrm{W}$ projekcie $\mathrm{z}$ haftu zrezygnowano właśnie na rzecz wycinanek, niejako zespajających tradycje hrubieszowskie z odniesieniami charakterystycznymi dla innego regionu. Pamiętać należy, że początkowo elementami dekoracyjnymi stroju hrubieszowskiego były jedynie czarne wzory, dopiero z czasem upowszechniły się kolorowe hafty ${ }^{19}$. Czarna kolorystyka była bezpośrednim odniesieniem do tradycji ludności ukraińskiej, zamieszkującej region przed II wojną światową, poniekąd także do lokalnych warunków naturalnych (do czarnoziemów przeważających na tym terenie). $\mathrm{W}$ strojach $\mathrm{z}$ nadwiślańskiego Urzecza również odnajdujemy wyraźne odniesienia do matki Ziemi, karmicielki, co skłoniło projektantkę do subtelnego, aczkolwiek zauważalnego zespolenia obu wzorów.

Wracając jednak do wiodącego tematu - zasadnicze pytanie brzmi: czy projekty Wyrwał to udana fuzja tradycji z nowoczesnością? Już na pierwszy rzut oka widoczna jest inspiracja strojem ludowym, jest on jednak mocno zmodyfi-

łowieckimi - oba produkty projektu Katarzyny Herman-Janiec. Studio Moho proponuje serie awangardowych dywanów o kształcie kurpiowskiej wycinanki. Inną uznaną firmą tworzącą dywany „czerpiące z tradycji” jest Sztuka Beskidzka. Nazwa może wprowadzać w błąd, gdyż firma sygnuje produkty, które w znaczącej mierze są inspirowane tradycjami Podlasia, nie zaś górskiego regionu południowej Polski. Anna Kotowicz-Puszkarewicz i Artur Puszkarewicz, twórcy marki AZE Design, zaprojektowali lampę Kokon, której abażur wykonany jest techniką szycia ze słomy. Nawiązując do starych technik rękodzielniczych, team AZE Design stworzył dywan Nodus, w formie przeskalowanej, okrągłej, szydełkowanej serwetki. Projektem Puszkarewiczów jest również dywan Folk, z ornamentem, który powstał z uproszczenia tradycyjnego wzoru białoruskiego oraz zgeometryzowania go na kształt wczesnej grafiki komputerowej. Folk łączy dawną technikę produkcji sukna, tzw. foliowanie, ze współczesnym sitodrukiem.

${ }_{17}$ Za. E. Piskorz-Branekova: Czy strój noszony w okolicach Hrubieszowa i Tomaszowa Lubelskiego możemy nazwać hrubieszowsko-tomaszowskim? Problem z terminologia. W: Stroje ludowe jako fenomen..., s. 151-160.

${ }^{18}$ Zob. zdjęcia promujące kolekcję: AGA POU. Zaplątani. https://agapou.com/zaplatani/ [data dostępu: 25.01.2019].

${ }_{19}$ E. Piskorz-Branekova: Tradycyjne stroje $i$ hafty hrubieszowskie i tomaszowskie. Zamość 2011, s. 44-46. 
kowany w fasonie, dopasowanym do klimatu mody ulicznej. Kroje niektórych ubrań sprawiają wrażenie unowocześnionych „na siłę, jednak kolekcji nie można odmówić spójności. Można rzec, że w tym wydaniu inspiracja strojem regionalnym jest świadoma i przemyślana; z pewnością nie jest też dosłowna, a elementy zapożyczone $\mathrm{z}$ tradycji ludowej są poddane znacznym przeobrażeniom. Odrzucając konwencje, Wyrwał przedkłada siłę wyrazu nad formę. Wszystko to razem tworzy obraz solidnego rzemiosła. Przygotowanie warsztatowe wpływa na artystyczny finalny obraz. Projektantka stara się pamiętać, że strój, będąc wartością, jednocześnie jest nośnikiem wartości. Dostarcza on bowiem znaczeń symbolicznych retoryce masowej konsumpcji, podlega mityzacji, przywołując „krainę utraconej szczęśliwości”. Widać to w zaaranżowanym skrzętnie powrocie tradycyjnych wzorów i detali dekoracyjnych, których znaczenie odbieramy intencjonalnie. Czasem trudno okiełznać pokusę zinternalizowania obszaru tego rodzaju zabiegów. Semantykę marginesu można odnieść do waloryzowania poprzez odpowiednią ekspozycję, w ten sposób elementy stroju wtórnie nabierają znaczenia, stając się jeszcze mocniej akcentowanym znakiem. W przypadku Wyrwał warto też wspomnieć, że jeden z męskich ubiorów jej autorstwa, po zwycięstwie projektu w konkursie zorganizowanym przez Muzeum Etnograficzne w Warszawie, stał się stałym elementem ekspozycji tego muzeum. Potwierdza to, że współcześni projektanci są dobrze zorientowani w panującej sytuacji, znają konteksty swojej działalności. Potrafią tworzyć etnograficzną fikcję dobrze wpisującą się w konwencję symultanicznego istnienia obu światów. Tym samym moda w stylistyce folk, przeciwstawiając się konwenansom, staje się pełna cytatów i autointerpretacji. Nowa kreacja przywodzi na myśl pewne typowe elementy stroju ludowego, nawiązujące jednak formą do wzorów współczesnej odzieży. $\mathrm{W}$ procesie tym moda pośredniczy, podsuwając formy zdolne do udźwignięcia określonych treści. Bywa jednak, że forma nie unosi treści i wówczas mamy do czynienia z kiczem.

W tym kontekście warto spojrzeć bliżej na projekty Anety Larysy Knap, tworzącej markę Folk Design. Absolwentka krakowskiej Szkoły Artystycznego Projektowania Ubioru propaguje ubrania inspirowane niemal wyłącznie kulturą ludową, wypełniając tym samym sporą lukę wciąż istniejącą na polskim rynku. Przedstawia nam mianowicie swoją wizję stroju podhalańskiego. Celem Knap, jak sama wskazuje, jest rozpowszechnianie walorów kulturowych regionu, z którego się wywodzi, oraz zwrócenie uwagi na często niedostrzeganą wartość estetyczną stroju regionalnego ${ }^{20}$. Idea artystki jest jak najbardziej zasadna. Kierpce na

${ }^{20}$ Projektantka w mediach społecznościowych przedstawia się jako prekursorka łączenia tradycji z nowoczesnością. Podkreśla przy tym, że zajmuje się tworzeniem „nowatorskiego stylu” bazującego na kanonicznych emblematach góralskiego folkloru. Zob. oficjalny profil w mediach społecznościowych: Folk Deisgn. https://facebook.com/folkdesignanetalarysaknap/ [data dostępu: 30.01.2019]. Zob. zdjęcia promujące markę: Folk Design. https://folkdesign.art-madam.pl/ubrania [data dostępu: 25.01.2019]; „Folk Design” Aneta Larysa Knap. NaLudowo.pl. https://naludowo.pl/folk 
obcasie czy jeansy tkane w góralską parzenicę mogą sugerować zbyt dosłowną inspirację ludowością, jednakże należy pamiętać, że celem projektantki było stworzenie kolekcji, w której każdy ma szanse odnaleźć coś dla siebie. Nie mogły się tu zatem pojawić ekstrawaganckie rozwiązania. Walorem jest z pewnością wykorzystanie autentycznych materiałów (na przykład tybetu). Warto także zwrócić uwagę na ręcznie wykonane malunki będące odwołaniem do tradycji ludowego rzemiosła. Folk Design to marka pełna kontrastów. Przeglądając propozycje projektantki, mamy wrażenie, że podróżujemy po istnym labiryncie estetycznym. Oprócz naprawdę obiecujących są też projekty mniej udane, jakby przygotowane naprędce tylko po to, aby zróżnicować asortyment. To sprawia, że trudno dostrzec jakiekolwiek konkretne ujęcie tematu. Folklor nie jest przecież gotowym stylem, a jedynie inspiracją w kreowaniu określonej odrębnej estetyki. Mimo to projektantce $\mathrm{z}$ pewnością nie można odmówić wyobraźni i odwagi. W wielu przypadkach jako wartość dodaną wprowadza element zaskoczenia, co powoduje jednak pewien metodologiczny zgrzyt. Propozycje Knap odważnie uwydatniają seksualność, a prezentacja projektów na fotografiach w mediach jest zaaranżowana $\mathrm{w}$ taki sposób, by niemal natychmiastowo przywoływać skojarzenia z obrazem wyuzdanej wiejskiej dziewczyny, znanej nam doskonale z popkulturowych działań medialnych.

Odważne rozwiązania, czasem znacznie odbiegające od tradycyjnej formy, proponuje zabrzanka Mirosława Szałasta, absolwentka Wydziału Wzornictwa katowickiej Wyższej Szkoły Technicznej, projektująca ubiory inspirowane górnośląskim strojem kobiecym. W kolekcji „Kolory Górnego Śląska. Adaptacja wzornictwa i elementów konstrukcyjnych bytomskiego stroju ludowego panny we współczesnych ubiorach damskich" przekłada jego elementy na futurystyczne wręcz wizje ${ }^{21}$. To dekonstrukcja stroju w ujęciu niemal derridowskim. Projekty narodziły się $\mathrm{w}$ wyniku zabawy formą zaczerpniętą bezpośrednio $\mathrm{z}$ estetyki stroju bytomskiego, zwanego też rozbarskim.

Jako nieodłączny element projektów pojawia się galanda, która przypomina jednak bardziej wianki prezentowane podczas występów zespołów regionalnych niż tę tradycyjnie zakładaną $\mathrm{w}$ trakcie swoistego rytuału. Jest wykonana $\mathrm{w}$ formie okręgu ze sztucznych kwiatów, a nie budowanej na drucianej podstawie konstrukcji zaplatanej na głowie. Brakuje, zapewne celowo pominiętych, klap przypinanych warstwowo z tyłu oraz wionuszka ze żdżadełkami mocowanego za

-motywy/moda-na-ludowo/aneta-larysa-knap-folk-design-moda-na-ludowo-nowy-targ-etno-pod hale-jeansy-z-parzenica-kierpce-na-obcasie.html [data dostępu: 27.01.2019].

${ }^{21} \mathrm{~W}$ odróżnieniu od poprzednich przykładów mamy tu do czynienia także z projektami nawiązującymi do konwencji high fashion, nieprzystającymi do wymogów codzienności. Zob. zdjęcia promujące kolekcję w: Tradycja w nowoczesnym wydaniu. „Górnoślązak. Gazeta Związku Górnośląskiego" 2016, nr 10 (17), s. 2. zg.org.pl/gazeta/gornoslazak-2016-nr-10-17 [data dostępu: 26.01.2019]; D. Chrost: Moda w kolorach Śląsk. Nowiny Zabrzańskie. nowinyzabrzanskie.pl/ gospodarka/moda-kolorach-slaska-galeria/ [data dostępu: 30.01.2019]. 
pomocą harnadli. W części środkowej znajduje się, jak w oryginalnych galandach, czerwona róża, trudno jednak ocenić, czy jest to zabieg świadomy czy też wynik przypadku. Raczej deformacja jest tu zabiegiem zamierzonym, mającym na celu wywołanie pewnego rodzaju skojarzenia, a nie rekonstrukcję dawnych elementów. Niewątpliwie jednak większa autentyczność w rewitalizacji dawnego stroju mogłaby wprowadzić - mimo sporej paradoksalności tego stwierdzenia nieznaną dotąd świeżość.

Strój rozbarski wymagał, aby sylwetka kobieca prezentowała się kopiasto i obficie. Chcąc osiągnąć zamierzony efekt, zakładano kilka spódnic spodnich albo jedną grubą watowaną lub pikowaną szytą z inletu, często noszono też stanik z kiełbasą/kiełbaśnicą. W projektach składających się na kolekcję „Kolory Górnego Śląska" elementy stroju dawniej typowo bieliźniane zostają wyeksponowane $\mathrm{w}$ formie mocno przeobrażonej, a ponadto celowo przedstawionej jako element wierzchni. Funkcję wielu warstw halek pełnią przestrzenne, symetrycznie zgeometryzowane konstrukcje. Mamy także i dosłowne odniesienie w formie kiełbaśnicy. Został do niej dołączony charakterystyczny ażurowy tren wykonany z pasów materiału przywodzącego na myśl dawne zapaski. W kolekcji zaznacza się wyraźnie przewodnia w założeniu Szałasty kolorystyka - mianowicie czerwień, żółć oraz ciemny niebieski. Wspomniane pseudozapaski, szlajfy przyczepione do galandy oraz te, które w kilku projektach tworzą coś na kształt ażurowej spódnicy, pozbawione są jakichkolwiek elementów ozdobnych, tradycyjnie obecnych. We wzorach na sukienkach, które stanowią odpowiednik kiecki z lajbikiem, pierwotnie zasłoniętej przez kabotek i wierzcheń, brak powtarzalności, tak charakterystycznej w zdobnictwie stroju rozbarskiego. Pojedynczy kwiatowy sporych rozmiarów motyw został wyhaftowany, a nie namalowany, jak to niegdyś czyniły Ślązaczki. Kabotek w zmienionej formie - z przedłużonymi rękawami, pozbawionymi jakichkolwiek ozdób (brak bufiastych rękawów oraz koronkowej kryzy przy ich zakończeniu) - nasuwa na myśl wizualną fuzję z mocno zredukowaną objętościowo formą jakli. Wierzcheń występuje $\mathrm{w}$ projektach $\mathrm{w}$ formie pozornie zbliżonej do oryginału; w zasadzie został zachowany tradycyjny krój, projektantka zrezygnowała natomiast $\mathrm{z}$ charakterystycznych elementów zdobniczych.

\section{Wnioski}

Niewątpliwie potrzebujemy oderwania od świata, w którym wszystko jest na sprzedaż. Paradoksalnie jednak również to, co postrzegane jako tradycyjne, rości sobie od dawna prawo do funkcjonowania w przestrzeni rynkowej. Warto się powstrzymać przed jednoznacznie negatywną oceną tego zjawiska, bo być może gdyby nie komercjalizacja elementów stroju ludowego, ten w ogóle odszedłby w zapomnienie czy byłby znany tylko wąskiemu gronu badaczy. Zgadzam się ze 
stwierdzeniem, że strój ludowy możemy klasyfikować jako element artystycznej spuścizny minionych pokoleń. Przez lata jednak tradycyjne wzory przerabiano i zastępowano (nie zawsze udanymi) imitacjami czy rekonstrukcjami, co doprowadziło do stłamszenia potencjału związanego z tym strojem. Mam tu głównie na myśli tę jego cechę, która pozwala jego nosicielowi wyrazić pewne idee tożsamościowe. Skłania to do pytań: Czy próby odtworzenia jego elementów nie są kolejnym zamachem na jego istotę? Czy to, co przejawia się w kombinacji obrazów towarzyszących współczesnym projektantom, nie jest jedynie żerowaniem na autentyzmie noszonego dawniej stroju ludowego? W niektórych bowiem przypadkach twórczość funkcjonująca pod szyldem folk fashion, wprzęgnięta w mechanizmy rynkowe, jest przejawem świadomego dążenia do profanacji tradycji. Być może jest to odważny wniosek, jednakże podnoszony już w literaturze przedmiotu. Artyści pytani, dlaczego podążają ludowymi śladami, odpowiadają niemal natychmiastowo i zaskakująco zgodnie, że wynika to $\mathrm{z}$ ich wewnętrznej potrzeby wyeksponowania wartości, jakie niesie z sobą autentyczna tożsamość kulturowa poszczególnych regionów. Możemy rzecz jasna podać taką interpretację w wątpliwość i, idąc dalej, zapytać, czy nie jest to tylko podążanie za tendencją? Jednakże nawet jeśli to tylko moda, to zdaje się niosąca z sobą szczytne ideały i, wbrew sceptycznym opiniom, zmierzająca w dobrą stronę.

Niezależnie od rzeczywistej motywacji cieszy fakt ponownego odkrycia stroju ludowego. Ważne jest, aby czerpiąc inspirację z ludowości, nie zatrzeć całkowicie konotacji dotyczących funkcjonujących rzeczywiście wartości. Chodzi zatem nie tylko o misternie odtworzony wzór nawiązujący do autentycznych zachowanych elementów, ale też o poszukiwanie głębszej więzi porozumienia nowego ze starym, które to porozumienie dokonuje się na platformie metaforycznego kontaktu. Równocześnie należy pogodzić się z tym, że żadne działania (włączając $\mathrm{w}$ to oczywiście działania podejmowane w ramach określonych grup folklorystycznych tudzież rekonstrukcyjnych) nie są wstanie podtrzymać tradycji noszenia stroju ludowego sensu stricte, naszym zadaniem natomiast jest opieka nad tą częścią tradycji, która współcześnie może stanowić źródło inspiracji. Na folk fashion warto spojrzeć zatem jako na swego rodzaju łamigłówkę, która wprowadza badaczy w zakłopotanie, prowadząc przez labirynt wzorów zespolonych przypadkowo czy według zasad znanych tylko projektantowi. Folk fashion jest czymś w rodzaju nieznanej formy tego, co już dobrze znane. Trzeba jedynie czasu, aby utraciło swoją obcość.

\section{Bibliografia}

„Folk Design” Aneta Larysa Knap. NaLudowo.pl. https://naludowo.pl/folk-motywy/moda-na-ludowo/ aneta-larysa-knap-folk-design-moda-na-ludowo-nowy-targ-etno-podhale-jeansy-z-parzenica -kierpce-na-obcasie.html [data dostępu: 27.01.2019].

AGA POU. Zaplątani. https://agapou.com/zaplatani/ [data dostępu: 25.01.2019]. 
BARAŃSKi J.: Świat rzeczy. Zarys antropologiczny. Kraków 2007.

BAZIelich B.: Kolory Europy. Odzież i stroje ludowe. Katowice 2008.

Bazielich B.: Z bliska i $z$ oddali. Stroje ludowe na Ślasku. Katowice 2017.

Benjamin W.: Twórca jako wytwórca. Poznań 1975.

BrZezińska A.W.: Strój ludowy - od biografii przedmiotu do tożsamości podmiotu. W: Stroje ludowe jako fenomen kultury. Red. A.W. BRzezińsкA, M. Tyмосноwicz. Wrocław 2013 (Atlas Polskich Strojów Ludowych. Zeszyt specjalny), s. 15-24.

BrZezińska A.W., SŁomska-NowaK J.: Czy i jak badać strój ludowy? W: Etnologiczne i antropologiczne obrazy świata - konteksty i interpretacje. Red. H. Ruser, A. PieńCzaK. Cieszyn 2011, s. $62-74$.

Burszta W.J.: Od mowy magicznej do szumów popkultury. Warszawa 2009.

Burszta W.J.: Świat jako więzienie kultury. Kraków 2008.

Снrost D.: Moda w kolorach Śląska. Nowiny Zabrzańskie. nowinyzabrzanskie.pl/gospodarka/ moda-kolorach-slaska-galeria/ [data dostępu: 30.01.2019].

Comaroff J.L.: Etniczność sp. z o.o. Przel. W. Usakiewicz. Kraków 2011.

Czerwińska K.: Strój jako wyzwanie artystyczne. W: EAdem: Przepakować dziedzictwo. Przeszłość jako projekcja rzeczywistości - przypadki ślaskie. Katowice 2018, s. 126-132.

Dagloví O.: Dekor symbol. Dekoratívna tradícia na Slovensku a európsky kontext. Bratislava 2001, s. $240-254$.

Etnoinspiracje. Inspiracje kultura ludowa we współczesnym polskim wzornictwie, modzie, architekturze, reklamie... Red. K. Kulikowska, C. Olbracht-Prondzyńska. Gdańsk 2012.

FišERová-KvĚchová H.: Lidové umění jako inspirační zdroj v díle Marie Fischerové-Kvěchové. „Studia Ethnologica Pragensia” 2016, č́slo 1, s. 41-50.

Folk Deisgn. https://facebook.com/folkdesignanetalarysaknap/ [data dostępu: 30.01.2019].

Folk Design. https://folkdesign.art-madam.pl/ubrania [data dostępu: 25.01.2019].

Frejlich C.: Ergonomia i wzornictwo. W: O!to design. Spotkanie z polskim designem / A Meeting with Polish Design. Łódź 2010, s. 48-49.

INGARDEN R.: Studia $z$ estetyki. T. 3. Warszawa 1975.

Корутоғғ I.: Kulturowa biografia rzeczy - utowarowienie jako proces. W: Badanie kultury. Elementy teorii antropologicznej. Wybór i przedm. M. KempnY, M. Nowicka. Warszawa 2003, s. 249-274.

Korduba P.: Ludowość na sprzedaż. Warszawa 2013.

Langhammerová J.: České tradice v proměnách času. Kroje - zvyky - umění. Praha 2017.

Mathews G.: Supermarket kultury. Kultura globalna a tożsamość jednostki. Przeł. E. Кцекот. Warszawa 2000.

Piskorz-Branekova E.: Czy strój noszony w okolicach Hrubieszowa i Tomaszowa Lubelskiego możemy nazwać hrubieszowsko-tomaszowskim? Problem z terminologia. W: Stroje ludowe jako fenomen kultury. Red. A.W. Brzezińska, M. Tyмосноwicz. Wrocław 2013 (Atlas Polskich Strojów Ludowych. Zeszyt specjalny), s. 151-160.

Piskorz-Branekova E.: Polskie stroje ludowe. Warszawa 2008.

Piskorz-Branekova E.: Tradycyjne stroje $i$ hafty hrubieszowskie i tomaszowskie. Zamość 2011.

Šotková B.: Naše lidové kroje, jejich vzory, střihy a zpracování. Praha 1952

Sulima R.: Supermarket - przyczynek do retoryki konsumpcji. W: Idem: Antropologia codzienności. Kraków 2002.

TAтAj D.: Od awangardy do innowacji. W: W kręgu sztuki przedmiotu. Red. M. DŁutek. Warszawa 2011, s. 38-48.

Tradycja w nowoczesnym wydaniu. „Górnoślązak. Gazeta Związku Górnośląskiego” 2016, nr 10 (17), s. 2. zg.org.pl/gazeta/gornoslazak-2016-nr-10-17 [data dostępu: 26.01.2019].

Tradycja wynaleziona. Red. E. Hobsbawn, T. Ranger. Przeł. M. Godyń, F. Godyń. Kraków 2008. 
Trebunia-Staszel S.: Podhalańskie elegantki i miejscowi kreatorzy mody. W: Stroje ludowe jako fenomen kultury. Red. A.W. Brzezińska, M. Tyмосноwicz. Wrocław 2013 (Atlas Polskich Strojów Ludowych. Zeszyt specjalny), s. 119-130.

Współczesna problematyka badań nad strojem ludowym. Red. A.W. BRzezińsкA, M. TYмосноwicz, A. Paprot-Wielopolska. Wrocław 2018 (Atlas Polskich Strojów Ludowych. Zeszyt specjalny). 